RNA 25: 897-904 (2019)

\title{
Corrigendum: Strategies for genetic inactivation of long noncoding RNAs in zebrafish
}

\author{
PERRINE LAVALOU, HELENE ECKERT, LOUISE DAMY, FLORIAN CONSTANTY, SARA MAJELLO, \\ ANGELO BITETTI, ANTOINE GRAINDORGE, and ALENA SHKUMATAVA
}

In the Acknowledgment section of the above-mentioned article, the authors omitted the funding sources ANR-11-LABX0044_DEEP and ANR-10-IDEX-0001-02. The Acknowledgment section has been corrected online to read as follows:

We thank all members of the Shkumatava laboratory and Ines Drinnenberg for useful discussions. This work was supported by grants from the European Research Council (FLAME-337440), ATIP-Avenir, La Fondation Bettencourt Schueller, ANR11-LABX-0044_DEEP, and ANR-10-IDEX-0001-02, as well as PSL and La Ligue Nationale Contre Le Cancer doctoral fellowships to P.L.

doi: $10.1261 /$ rna.074989.120 

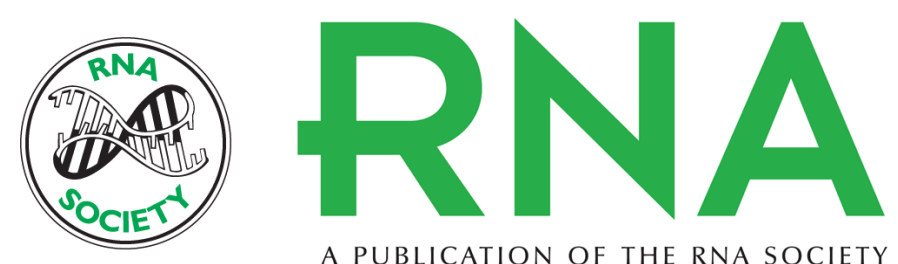

A PUBLICATION OF THE RNA SOCIETY

\section{Corrigendum: Strategies for genetic inactivation of long noncoding RNAs in zebrafish}

Perrine Lavalou, Helene Eckert, Louise Damy, et al.

RNA 2020 26: 529

\section{Related Content Strategies for genetic inactivation of long noncoding RNAs in zebrafish Perrine Lavalou, Helene Eckert, Louise Damy, et al. \\ RNA August , 2019 25: 897-904}

Open Access Freely available online through the RNA Open Access option.

License Email Alerting $\begin{aligned} & \text { Receive free email alerts when new articles cite this article - sign up in the box at the } \\ & \text { Service }\end{aligned}$ top right corner of the article or click here.

To subscribe to $R N A$ go to:

http://rnajournal.cshlp.org/subscriptions 